\title{
MicroRNA-103a curtails the stemness of non-small cell lung cancer cells by binding to OTUB1 through the Hippo signaling pathway
}

Zhenzhen Hu

Jiangxi Tumor Hospital

Dan Xiao

Jiangxi Tumor Hospital

Tingting Qiu

Jiangxi Cancer Hospital

Jun Li

Jiangxi Tumor Hospital

Zhentian Liu ( $\square$ Liuzhentian120902@163.com )

Jiangxi Tumor Hospital https://orcid.org/0000-0002-7436-8874

Research

Keywords: microRNA-103a, OTUB1, The Hippo pathway, Non-small cell lung cancer, Cancer stem cells

Posted Date: September 9th, 2020

DOI: https://doi.org/10.21203/rs.2.24459/v2

License: (c) (i) This work is licensed under a Creative Commons Attribution 4.0 International License.

Read Full License 
The authors have withdrawn this preprint from Research Square 